\begin{tabular}{|c|c|c|}
\hline $\begin{array}{l}\text { PUCRS } \\
\text { PUCR }\end{array}$ & $\begin{array}{l}\text { ESCOLA DE CIÊNCIAS } \\
\text { DA SAÜDE E DA VIDA }\end{array}$ & $\begin{array}{l}\text { Psico, Porto Alegre, v. 51, n. 1, p. 1-11, jan.-mar. } 2020 \\
\text { e-ISSN: 1980-8623 | ISSN-L: 0103-5371 }\end{array}$ \\
\hline def http & oi.org/10.15448/1980-8623.2020.1.28367 & \\
\hline
\end{tabular}

ARTIGO ORIGINAL

\title{
Benefits of relaxation techniques in the elderly: a systematic review
}

\author{
Benefícios das técnicas de relaxamento em idosos: uma revisão sistemática \\ Beneficios de las técnicas de relajación en ancianos: una revisión sistemática
}

Andréa dos Santos-Silva ${ }^{1}$ orcid.org/0000-0001-9403-775X andreadosantos2011@gmail.com

\section{Milena Nardini Bubols ${ }^{1}$}

orcid.org/0000-0002-5558-4985 milena.bubols@edu.pucrs.br

\section{Irani Iracema de Lima Argimon ${ }^{1}$} orcid.org/0000-0003-49840345 argimoni@pucrs.br

\section{Olivia Stagnaro²} orcid.org/0000-0002-4975-8758

\section{Letícia Oliveira}

Alminhana $^{1}$

orcid.org/0000-0001-8829-4493 leticia.alminhana@pucrs.br

Recebido em: 24 ago. 2017. Aceito em: 6 mai. 2018. Publicado em: $x x$ xxx. 2020
Abstract: The goal of this Clinical Psychology study was to present the possible therapeutic effects of Relaxation Techniques in elderly people. The systematic review was conducted by two researchers who performed inquiries independently in the following databases: PubMed, Psyclnfo, Scopus and Lilacs in June 2015 using the string: "relaxation" OR "relaxation therapy" AND "elderly people." The initial selection resulted in 244 articles and, from the criteria for inclusion and exclusion, 11 studies were analysed for this review as of May 2017. This research found evidence of the effectiveness of Relaxation Techniques in elderly populations, especially in reducing symptoms of anxiety, related cognitive difficulties, physical symptoms, especially tension headaches and increasing immunity through the diminishment of stress.

Keywords: relaxation, relaxation technique, elderly people.

Resumo: Este estudo tem como área temática a psicologia clínica e o seu objetivo foi apresentar os possiveis efeitos terapêuticos das técnicas de relaxamento para idosos. A revisão sistemática foi conduzida por dois pesquisadores, que realizaram as buscas de forma independente nas seguintes bases de dados: PubMed, PsycInfo, Scopus e LILACS, em junho de 2015, utilizando a string: "relaxation" OR "relaxation therapy" AND "elderly people". A seleção inicial resultou em 244 artigos e, a partir de critérios de inclusão e exclusão, foram analisados 11 estudos para esta revisão até maio de 2017. Foram encontradas evidências de eficácia das técnicas de relaxamento na população idosa, principalmente na redução de sintomas de ansiedade, bem como de dificuldades cognitivas a ela relacionadas e redução de sintomas físicos, sobretudo dores de cabeça tensionais e aumento da imunidade através da diminuição das consequências do estresse. Palavras-chave: relaxamento, técnica de relaxamento, idosos.

Resumen: Este estudio abarca el ámbito temático de la Psicologia Clinica y tiene como objetivo mostrar posibles efectos terapéuticos de las Técnicas de Relajación en ancianos. La revisión sistemática fue conducida por dos investigadores, que realizaron sus investigaciones independientemente en las siguientes bases de datos: PubMed, Psyclnfo, Scopus y Lilacs en Junio de 2015. utilizando el string "relaxation" OR "relaxation therapy" AND "elderly people". La selección inicial resultó en 244 artículos. Desde criterios de inclusión y exclusión, hasta mayo de 2017 fueron analizadas 11 investigaciones para este estudio. La investigación encontró evidencias de la eficacia de las Técnicas de Relajación en personas mayores, reduciendo sobre todo sintomas de ansiedad, así como problemas cognitivos a ella relacionados y también en la reducción de síntomas físicos, como cefaleas tensionales y aumento de inmunidad por la disminución de los efectos del estrés.

Palabras clave: relajación, técnicas de relajación, ancianos. 
Relaxation began to be studied in 1908 at the Harvard Laboratory of Experimental Psychology. Later the method was brought to other universities, more extensively developed in research at the Human Physiology laboratory at Chicago University (Jacobson, 1925). Progressive Relaxation appeared from the observation of relaxation as a natural physiological function of the body, but the goal of the research was to develop control of this function to benefit the organism. It was discovered that if it were possible to calm the sensory impulses through a gradual and generalized relaxation, the mind would correspond, quieting down as well (Jacobson, 1924).

Later, Benson (Benson \& Stark, 1998) studied the answer to "fight or flight," described by Cannon, and the "general adaptation answer to stress", described by Selye, as well as physiological reactions resulting from stressful situations. As a rebuttal to these physiological changes from stress came the "Relaxation Response," in which the heart beat reduces, breathing rhythm, metabolic rate and brain waves slow and the blood pressure decreases.

Within the study of body-mind incorporation, we find the field of Psychoneuroimmunology that has been applying an integrative concept of human beings since the 70's. This approach embraces the vision of preserving health in diverse human dimensions: physical, emotional, mental and spiritual. In this understanding of a person as an unit, it is the human that is healthy or sick and not one of his parts (Azambuja, 2000). In this sense, relaxation techniques bring this experience of incorporation, since it is in the physiological response resulting from this technique that the stress reduction occurs (Epstein, 2009). To evoke the Relaxation Response, it is suggested to focus and concentrate, repeatedly, on a word, sentence, sound or activity that has positive or pleasant meaning to the person, and it can be done through techniques such as Yoga, meditation, prayers, Progressive Muscular Relaxation, guiding images, etc. The frequent evocation of the Relaxation Response allows the body to reestablish and respond in a healthier manner to stressful factors (Benson \& Stark, 1998; Chang, Casey, Dusek, \& Benson, 2010).

Currently, the different relaxation techniques are used through diverse approaches and psychotherapy methods. In addition, Progressive Relaxation or Guided Visualization can be practiced individually or in groups and are an accessible option for public health insurances. In particularly, populations that are especially vulnerable to symptoms of stress, such as in grief, terminal patients, and elderly people can greatly benefit from these techniques (Chang et al., 2010).

According to the World Health Organization (WHO), between 1970 and 2025 there will be an increase of around $223 \%$ in the age range of 60 years or higher (WHO, 2005). And by 2050, 80\% of this population, around 2 billion people over the age of 60 , will be in the developing countries. This data shows that global population aging will be a great global challenge with a considerable increase in social and economic demands.

The changes that occur in the aging process, such as physical and cognitive decline, appearance of diseases, modifications in financial and social condition due to retirement, loss of loved ones, family distance and isolation may be experienced as stress causing situations (Vivian \& Bicca, 2015).

On the other hand, the concept of old age is changing in that in this phase of live, we can have personal accomplishments, higher maturity and wisdom. However, to many elderly, life quality means the ability to take care of yourself independently, which still represents a challenge (Argimon, Stein, Xavier, \& Trentini, 2004).

Quality of life is defined by WHO as an individual perception of position in life within the context of culture, values system in relation to the individual's objectives, expectations, patterns and concerns (The World Health Organization quality of life assessment (WHOQOL, 1995). In the end of the 9o's, WHO adopted the term "active aging", which represents the process of creating more favorable conditions of health, participation and safety opportunities, with the objective of increasing life quality as people get older. This term refers to the physical, social, and mental well-being in the course of life of individuals and groups and active and continued participation of elderly people in economic, social, cultural, spiritual, and civil matters (WHO, 2005). 
Therefore, promotion of health and quality of life in old age becomes indispensable as an answer to the elderly population increase, helps to face stressful situations and develop certain abilities. Aiming to promote health in this population, we can use preventive and/or therapeutic interventions, such as Relaxation Techniques (Argimon, Esteves \& Wendt, 2015; Burmeister, Argimon, \& Cataldo Neto, 2016). With that in mind, we performed a systematic review with the aim of presenting the "State of the Art" therapeutic effects of Relaxation Techniques for the elderly population.

\section{Method}

The present systematic review was conducted by two researchers (LA and AS), who independently performed searches according to the guidelines from PRISMA in the following databases: PubMed, Psyclnfo, Scopus, LILACS and Scielo in May of 2017. After selecting terms consulting Thesaurus and Mesh, the researchers opted for the following string: "relaxation" OR "relaxation therapy" AND "elderly people." The following filters were used to select the articles in the databases: a) the terms should be included in the title or abstract of the articles; b) only articles; c) research with humans; and d) written in English, Spanish or Portuguese.

Together, the same researchers (LA and AS), included articles in the study according to the following criteria: empirical studies that had original data, specifically including elderly population (59 years or older) and that presented relaxation techniques as a therapeutic tool. Duplicate works, philosophical essays or revisions, editor's letters, works including other age groups or that did not specify age group of the subjects and works which methods could produce as an effect some sort of relaxation, not focusing on relaxation as a technique, but using the word itself associated with other practices, for instance: mindfulness, dance, music, massage, biofeedback, etc. were excluded.

After the articles were filtered through the reading of titles and abstracts according to the criteria for inclusion and exclusion, manual searches in the articles' bibliographic references commenced with the intent of identifying other articles that fit in the parameters established for this research. Then, the following data was extracted from the articles and compiled in the results section: authors, year, publication country, used technique, type of study and results. All of the authors of the present study decided to organize the papers according to its main issue and describe it in sub-sections along results.

\section{Results}

The initial selection resulted in 244 articles. Of these, 25 were found in PubMed, 58 in Scopus, 153 in Psyclnfo and 8 in LILACS, and no articles were found in Scielo. Afterwards, 30 were removed for being duplicates, leaving a total of 214 for analysis. A total of 11 studies were selected for this review.

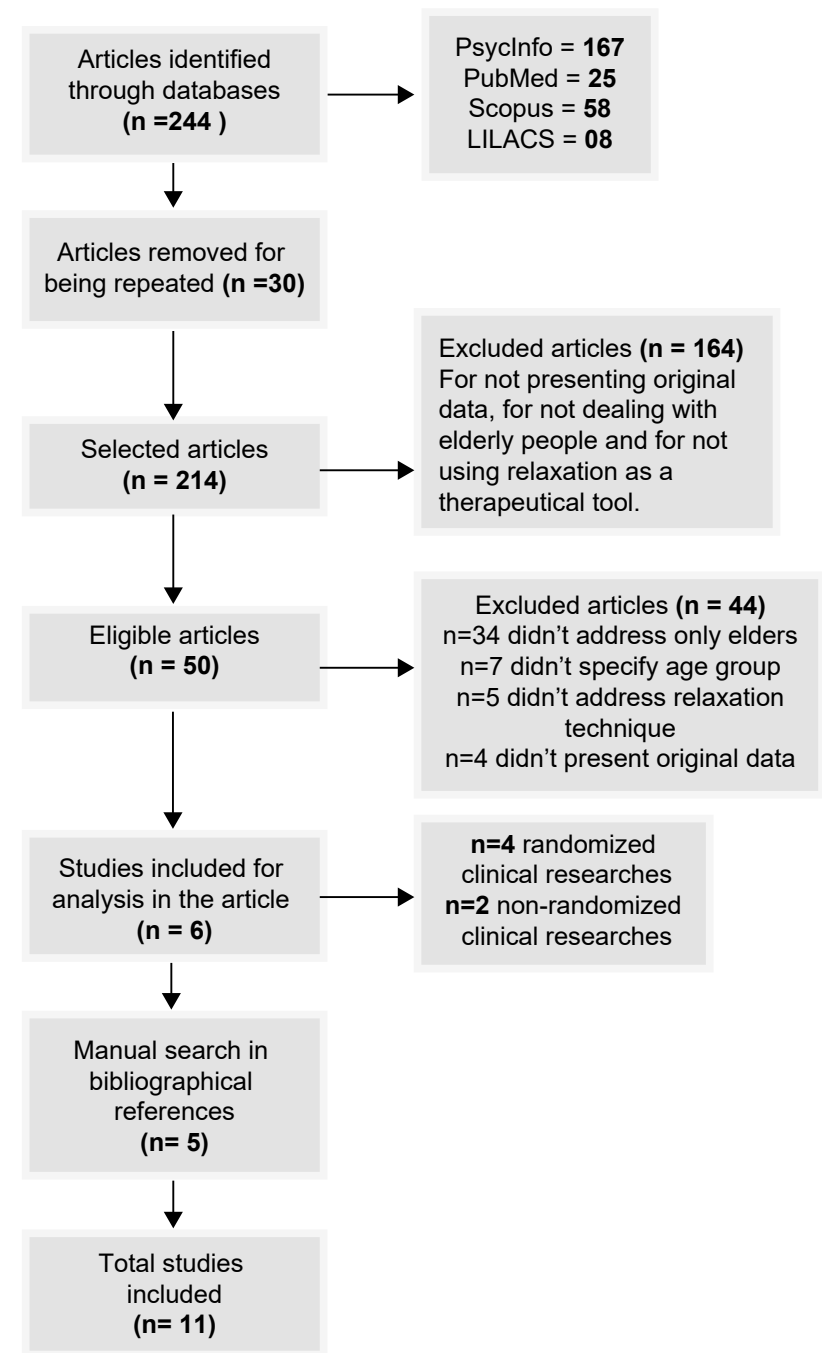

Image 1 - Flowchart of studies search and selection ( $n=$ studies) 
Table 1 presents a synthesis of the main results found in this review. Out of the total of 11 studies collected for the sample, 7 of them are randomized clinical studies and 4 are nonrandomized clinical studies, and only 2 of them were conducted outside the United States.

In 2 of the studies, participants were all women, composing a total of 93 participants (DeBerry, 1982; Lichstein \& Johnson, 1993). In the other 9, there were men and women, although only
$28.88 \%$ of the total of the samples $(N=392)$ were male (Arena, Hightower, \& Chong, 1988; Friedman, Bliwise, Yesavage, \& Salom, 1991; Galvin, Benson, Deckro, Fricchione \& Dusek, 2006; Lichstein, Riedel, Wilson, Lester, \& Neal, 2001; Reig-Ferrer et al., 2014; Scogin, Rickard, Keith, Wilson, \& McElreath, 1992; Yesavage \& Jacob, 1984; Yesavage, Rose, \& Spiegel, 1982; Yu, Lee, \& Woo, 2007). In a general scope, the participants of the studies were between 59 and 92 years old.

\begin{tabular}{lcccc}
\hline ARTICLE & OBJECTIVE & $\begin{array}{l}\text { NUMBER OF } \\
\text { SUBJECTS/ } \\
\text { GENDER/AGE }\end{array}$ & $\begin{array}{c}\text { TYPE OF STUDY/ } \\
\text { PROCEDURES }\end{array}$ & $\begin{array}{c}\text { USED } \\
\text { TECHNIQUE }\end{array}$ \\
\hline
\end{tabular}

$\begin{array}{ll} & \text { Observe if rela- } \\ \text { De Berry, } & \text { xation reduces } \\ \text { anxiety, tension } \\ 1982 & \text { and vegetative } \\ \text { USA } & \text { signs of depres- } \\ & \text { sion }\end{array}$

Scogin et al., 1992 USA

$N=36$
Female
63 to 79 years old

Randomized study 3 groups:

1) relaxation-meditation with follow-up;

2) relaxation-meditation without follow-up; 3) pseudo-relaxation control

After 10 weeks, group with follow-up received recordings with relaxation instructions for daily practice at home

Randomized study 3 groups: 1) progressive rela-

\section{Observe if the} techniques of the Progressive Relaxation or Relaxation with Imagination reduce anxiety
$N=54$

PR group mean =

68,9 years

IR group mean = 68,0 years DT group mean = 67,6 years xation;

2) relaxation with imagination;

3) control group.

All evaluated to

anxiety, capacity of absorption, physical relaxation, psychopathological symptoms and well-being in pre and post-treatment

Continuous relaxation and meditation

Progressive Muscular Relaxation and Meditation

\section{Progressive}

Relaxation

(Bernstein and

Borkovec,1973)

and Relaxation

with imagina-

tion (consisted

in imagining

the same ope-

rations from

the Progressi-

ve Relaxation)
Significant improvement in psychiatric symptoms and reduction in anxiety state practice maintain anxiety rates low and effectively reduce state/ trace of anxiety and depressive symptoms . 


\begin{tabular}{ccccc}
\hline ARTICLE & OBJECTIVE & $\begin{array}{c}\text { NUMBER OF } \\
\text { SUBJECTS/ } \\
\text { GENDER/AGE }\end{array}$ & $\begin{array}{c}\text { TYPE OF STUDY/ } \\
\text { PROCEDURES }\end{array}$ & $\begin{array}{c}\text { USED } \\
\text { TECHNIQUE }\end{array}$ \\
\hline
\end{tabular}

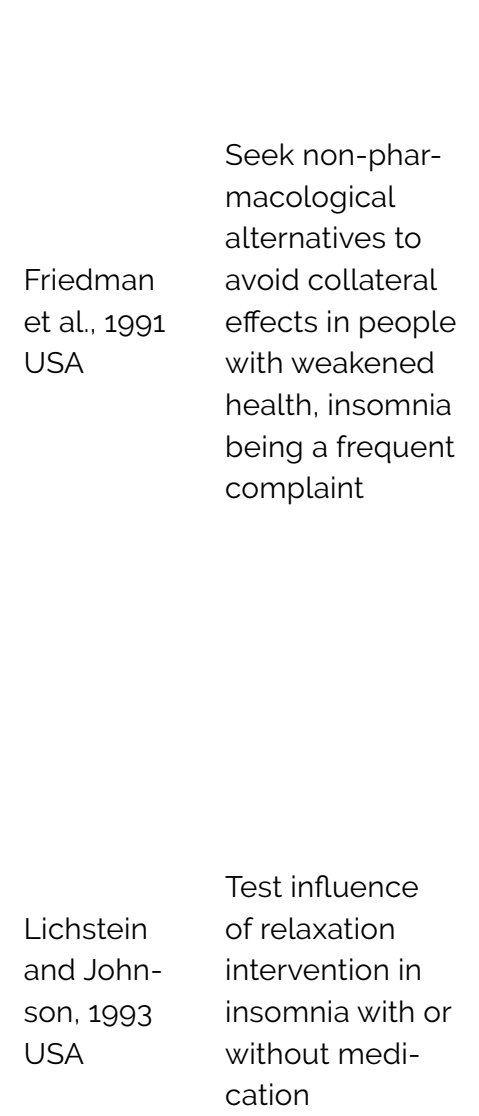

Lichstein et al., 2001 USA

Non-randomized

study - 2 groups:

1) Progressive Muscular Relaxation;

$\mathrm{N}=22$

$\mathrm{N}=14$ female

$\mathrm{N}=08$ male

$\mathrm{SRT}$ group mean = 66,6 years

$\mathrm{RLT}$ group mean = 71,8 years

$\mathrm{N}=57$

Female

60 to 80 years old cation
2) Sleep Restriction

Treatment

All participants

were submitted to

4 sessions of active

treatment of one

hour of duration

each, during 4 we-

eks. 3 months after,

they did a 2 week

follow-up

Non-randomized

study- 3 groups:

1) use of hypnotic medication;

2) non medications;

3) non-insomniacs

participants received

questionnaires, com-

pleted a journal of

sleep and consumed

medications during

a week. (post-treat-

ment and follow-up

of 6 weeks)

Randomized study

Participants received

sleep hygiene ins-

tructions 3 groups: a)

$\mathrm{N}=74$

$\mathrm{n}=53$ female

$\mathrm{n}=21$ male

59 to 92 years old
Progressive

Muscular

Relaxation

(standard Pro-

gressive Rela-

xation with the

exception of

neck and back),

and Sleep

Restriction Tre-

atment(creation

of their sleep

schedule)

Increase in total

bed-time and

decrease of awa-

kenings in the

Sleep Restriction

group was twice

higher than the

Relaxation group

Hybrid Relaxa-

tion for all the

participants

identical treat-

ment (created

by the author)

Non-medicated insomniacs presented positive changes in all measurements; group of medicated insomniacs diminished use of medication

Hybrid Relaxation (created by the author), Sleep Compression Treatment and Placebo Desensitization

Relaxation and Sleep Compression groups produced significant improvement over time in each sleep variable; after one year, Sleep Compression group presented better results 


\begin{tabular}{ccccc}
\hline ARTICLE & OBJECTIVE & $\begin{array}{l}\text { NUMBER OF } \\
\text { SUBJECTS/ } \\
\text { GENDER/AGE }\end{array}$ & $\begin{array}{c}\text { TYPE OF STUDY/ } \\
\text { PROCEDURES }\end{array}$ & USED TECHNIQUE \\
\hline
\end{tabular}

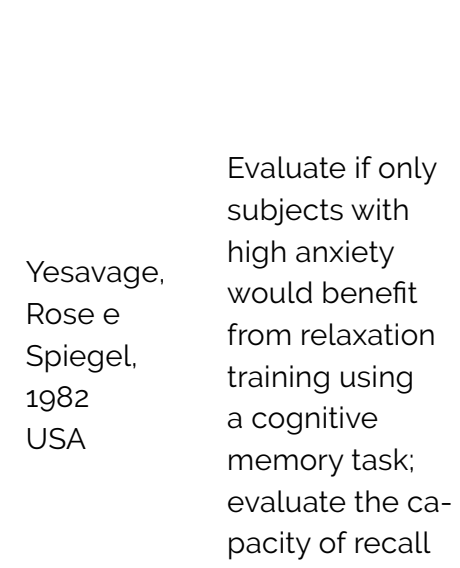

Yesavage e Jacob, 1984 USA

Arena,
Hightower
e Chong,
1988
USA

Galvin et al., 2006 USA

pacity of recall

Observe if

relaxation and mnemonic techniques would increase the capacity of memorization and attention and reduce anxious rumination Investigate the effects of relaxation training on tension headache ponse Training Program would levels, improve attention, decla-

\section{$N=26$}

$\mathrm{N}=16$ female

$\mathrm{N}=10$ male

Average age of

69.3 years

\section{$\mathrm{N}=25$ \\ $\mathrm{N}=20$ female \\ $\mathrm{N}=05$ male \\ 61 to 82 years old}

\section{Non-randomized}

study

4 weeks intervention

(1h50min); partici-

pants received a brochure with relaxation instructions; after the 3rd session, a cognitive memory test was held. Then, they were submitted to fifteen minutes of relaxation training. Still in relaxation state, a new a cognitive memory test was held.

Non-randomized study Relaxation training was held during the application of the anxiety and attention scales. Post-relaxation: cognitive test.

Non-randomized study; participants were monitored for

$\mathrm{N}=10$

$\mathrm{N}=05$ female

$\mathrm{N}=05$ male

62 to 80 years old

headaches in the

period of two weeks

before the beginning

of the study.

8 weeks of treat-

ment and home

practice twice a day.

Evaluate whether a Relaxation Resdecrease anxiety $\quad \mathrm{N}=15$ rative memory performance and/or decrease salivary cortisol levels
$\mathrm{N}=08$ female

$\mathrm{N}=07$ male

66 to 80 years old

Randomized study

Control group: 7;

Relaxation group: 8

Cortisol salivary samples were collected before and after the memory test and after 5 weeks of relaxation training: Participants completed daily record sheets

Only elderly

Standard people with high Progressive levels of anxiety Muscular Rela- improved in the xation; recall task after Relaxation

Modified

Progressive Muscular Relaxation

Progressive muscular relaxation therapy

\section{Relaxation Response Training}

Relaxation training improved memory with increase of attention from elderly people that had their anxiety diminished

Reduction in headache (clinical improvement) Significant clinical improvement and statistics in headache-free days and in headache's classification peak

RR group presented significant reduction in state of anxiety levels, in one aspect of memory and improvement in the performance of simple attention tasks 


\begin{tabular}{|c|c|c|c|c|c|}
\hline ARTICLE & OBJECTIVE & $\begin{array}{l}\text { NUMBER OF } \\
\text { SUBJECTS/ } \\
\text { GENDER/AGE }\end{array}$ & $\begin{array}{l}\text { TYPE OF STUDY/ } \\
\text { PROCEDURES }\end{array}$ & $\begin{array}{c}\text { USED } \\
\text { TECHNIQUE }\end{array}$ & RESULTS \\
\hline $\begin{array}{l}\text { Yu, Lee e } \\
\text { Woo, } 2007 \\
\text { China }\end{array}$ & $\begin{array}{l}\text { Examine the } \\
\text { effects of Pro- } \\
\text { gressive Muscle } \\
\text { Relaxation } \\
\text { Training on the } \\
\text { psychologic dis- } \\
\text { tress and dysp- } \\
\text { nea and fatigue } \\
\text { in patients with } \\
\text { heart failure. }\end{array}$ & $\begin{array}{l}N=121 \\
N=60 \text { male } \\
N=61 \text { female } \\
\text { average age of } \\
76.2 \text { years }\end{array}$ & $\begin{array}{l}\text { Randomized study } \\
\text { Intervention group: } \\
\text { 59; Control group: } 62 \\
\text { 10. Progressive } \\
\text { Muscular Relaxation } \\
\text { was taught and each } \\
\text { participant received } \\
\text { a guide with images; } \\
\text { 20. technique was } \\
\text { demonstrated with } \\
\text { an audio tape; 30. } \\
\text { participants practiced } \\
\text { relaxation therapy at } \\
\text { home twice a day; } \\
\text { phone follow-up in } \\
\text { the 4th, 6th and 8th } \\
\text { week. Post treatment: } \\
\text { 14th week. }\end{array}$ & $\begin{array}{l}\text { Progressive } \\
\text { Muscle Rela- } \\
\text { xation }\end{array}$ & $\begin{array}{l}\text { Reduced depres- } \\
\text { sion demonstra- } \\
\text { ting therapeutical } \\
\text { value in patients } \\
\text { with cardiac insu- } \\
\text { fficiency, but did } \\
\text { not reduce anxie- } \\
\text { ty as expected }\end{array}$ \\
\hline $\begin{array}{l}\text { Reig-Ferrer } \\
\text { et al., } 2014 \\
\text { Spain }\end{array}$ & $\begin{array}{l}\text { Evaluate Ben- } \\
\text { son's Relaxation } \\
\text { Response tech- } \\
\text { nique to improve } \\
\text { the psychologi- } \\
\text { cal well-being } \\
\text { and the immune } \\
\text { parameters of } \\
\text { elderly residents } \\
\text { of geriatric } \\
\text { homes }\end{array}$ & $\begin{array}{l}N=30 \\
N=23 \text { female } \\
N=07 \text { male } \\
74 \text { to } 91 \text { years old }\end{array}$ & $\begin{array}{l}\text { Randomized study } \\
\text { in which participants } \\
\text { were designated to } \\
\text { either the treatment } \\
\text { or control group; } \\
\text { they passed through } \\
\text { a functional evalua- } \\
\text { tion of daily activities } \\
\text { and responded to } \\
\text { scales of satisfac- } \\
\text { tion of life, affection, } \\
\text { general health, and } \\
\text { others; physical and } \\
\text { hematological pa- } \\
\text { rameters were also } \\
\text { investigated. The } \\
\text { participants were } \\
\text { evaluated after the } \\
\text { end of the treatment, } \\
\text { in a follow-up of up } \\
\text { to } 3 \text { months. }\end{array}$ & $\begin{array}{l}\text { Relaxation } \\
\text { Response } \\
\text { technique } \\
\text { created by } \\
\text { Benson }\end{array}$ & $\begin{array}{l}\text { Significant de- } \\
\text { cline in psycho- } \\
\text { logic anguish } \\
\text { and decline of } \\
\text { negative affect; } \\
\text { modulated a few } \\
\text { immune parame- } \\
\text { ters, improving } \\
\text { life quality }\end{array}$ \\
\hline
\end{tabular}

Two studies indicated that relaxation can be an effective procedure to reduce states of anxiety and depression in elderly people. The studies also demonstrated that the continuity of the sessions seems to provide higher relaxation. Therefore, the more frequent and continued the practice, the higher the decline of depression and anxiety symptoms (DeBerry, 1982; Scogin et al., 1992).
Three studies observed Relaxation Techniques as Treatment for Insomnia, even though only in the study in which the same technique was applied in different groups relaxation showed to be effective in the improvement of sleep quality (Lichstein \& Johnson, 1993). In the two studies where there was a comparison between relaxation and specific techniques to treat insomnia (Sleep Compression 
and Sleep Restriction), these techniques presented better results, especially in long term (Friedman et al., 1991; Lichstein et al., 2001).

It was also observed that the use of Relaxation helped reduce anxiety and memory problems. Two studies showed anxiety as a cognitive factor, interfering in the performance of memory and attention tasks. Relaxation training seemed to reduce anxiety and consequently to improve elderly people's memory and/or attention (Yesavage \& Jacob, 1984; Yesavage et al., 1982). In four studies, Relaxation was evaluated for the treatment of physical symptoms. It was associated to the improvement of the immunological system, to reduce tension headaches, and it has shown to be beneficial in a general manner to patients with cardiac insufficiency. In addition, the affective states studied as a whole, such as psychological anguish, depression and negative affectation presented significant improvement, which contributes to the increase in quality of life and improvement of physical symptoms (Arena et al., 1988; Galvin et al., 2006; Reig-Ferrer et al., 2014; Yu et al., 2007).

In short, study results point to the effectiveness of the technique, except when relaxation is compared to treatments for insomnia.

\section{Discussion}

The aim of this study was to review the academic literature about the possible therapeutic effects of Relaxation Techniques. Relaxation is a lowcost asset, drug-free and with relatively simple application, which makes the investigation of its benefits relevant, especially to the elderly population. In relation to the location of the studies, except for two of them (one in Spain and one in China), all of them were conducted in the United States. It is likely that this is due to the historic rescue promoted by Herbert Benson at Harvard University School of Medicine and the impact of what he called "Relaxation Response," in the United States, during the 80-90's (Benson \& Stark, 1998). That is probably the reason why most of the studies in this review were from those two decades. A meta-analysis from 2009 showed the same increase of studies at this period of time and, after the decade of 2000, there were many more studies investigating relaxation along with other psychotherapeutic techniques. To evaluate the efficacy of different types of behavioral treatments for geriatric anxiety, the effects from 19 trials were compared. Analyses were based on uncontrolled outcomes (comparing posttreatment and pre-treatment scores), and effects related to control conditions on both anxiety and depressive symptoms. Treatments for older adults with anxiety symptoms were, on average, more effective than active control conditions. Effects were comparable to those reported elsewhere for CBT for anxiety in the general population or for pharmacotherapy in older adults with anxiety. CBT (alone or augmented with RT) does not appear to add anything beyond RT alone, although a direct comparison is challenging, given the differences in control groups. Effects on depression symptoms were smaller, with no differences among treatment types. Results suggest that behavioral treatments are effective for older adults with anxiety disorders and symptoms. However, results must be interpreted with caution, given the limitations of the literature, including differing sample characteristics and control groups across studies (Thorp et al., 2009).

In addition, the percentage of female participants was higher than the male percentage, as shown in the previous section. In two studies with elderly women, the number of men that volunteered to participate was so reduced that the researchers opted to carry out the study only with women (DeBerry, 1982; Lichstein \& Johnson, 1993). We can infer that elderly men demonstrate less interest in participating in research or that men, statistically, present lower life expectation, making the group of women who reach senility higher (Bebbington, 1988; Bhayat, Das-Gupta, Smith, McKeever, \& Hubbard, R, 2009; Camargos \& Gonzaga, 2015; Garcia-Garcia et al., 2014; Petrov, 2007).

An issue taken into account was that some elderly people present physical limitations, resulting in difficulties while performing relaxations that involve tensing and relaxing certain muscles. Thus, the authors suggest that relaxation through 
imagination can be an alternative to progressive muscular relaxation, and it may have the same clinical use (Scogin et al., 1992).

On the other hand, both studies which analysed the influence of Relaxation Techniques for anxiety and depression symptoms indicated that relaxation can be efficient in reducing traces/states of symptoms, revealing that daily relaxation practice can bring benefits to the elderly population (DeBerry, 1982; Scogin et al., 1992). Based on a wide population sample, a 2015 study shows that the prevalence of anxiety disorders in the world is $33.7 \%$ throughout the lifespan (Bandelow \& Michaelis, 2015). However, the authors suggest that the elderly population has very specific characteristics and cannot be classified among the criteria of mental disorders manuals. Thus, aging and all aspects related to it presents factors that can lead to what the authors recognize as a "natural anxiety" or expected anxiety (Bandelow \& Michaelis, 2015). This understanding, added to the result of the studies reviewed in this article, shows the importance of techniques to decrease levels of stress and anxiety, such as relaxation for the elderly population.

It is known that anxiety and depression directly affect cognitive aspects such as attention and memory. The studies reviewed in this article suggest that the relaxation technique favored the mnemonic abilities directly associated to the participants' levels of anxiety. A few studies report a high incidence of diseases that directly affect memory in the elderly population, such as Alzheimer's (Fox, Knapp, Andrews, \& Fincher, 2013: Kuller \& Lopez, 2011). It is possible that techniques that improve attention and mnemonic capacity act in preventive form to these diseases. However, in this review, no specific studies about relaxation for the prevention of dementia or even Alzheimer's were found.

Future studies of possible benefits of Relaxation Techniques in elderly people could be specifically directed into two big fields: 1. prevention/treatment of anxiety, controlling associated variables, such as depression and cognitive difficulties; 2 . prevention/treatment of physical symptoms, such as pain, immunity and cardiopathies. In regard to physical factors, the studies included in this review demonstrate that relaxation techniques can reduce tension headache, benefit patients with cardiac insufficiency, reduce physiological symptoms of stress and positively act in the immune system, resulting in higher psychological well-being and quality of life. However, even though the results were promising, some authors recognize that relatively small samples limit results from being generalized to a wider population (Arena et al., 1988; Galvin et al., 2006).

Another interesting finding of the data is that the majority of the studies requested that the subjects also performed the relaxation training in their houses, with daily practices, sometimes more than once a day. However, some studies show that elderly people do not respond well when part of the technique has to be performed individually at home, due to problems of memory, cognition, physical limitations or because the elderly population can be more resistant to change of habits (Arena et al., 1988). Other authors suggest that this difficulty could be solved by giving the elders a recording of the therapist voice performing the relaxation technique to be listened at home, or even having it given in writing. This would promote the direct participation of the participant in the technique and, as a consequence in the treatment, it would bring a sensation of competence and capacity for the elders (DeBerry, 1982).

Relaxation techniques can be applied by different professionals in the health arena. They are economic interventions and its cost makes them a viable alternative in relation to the traditional psychological treatments, and they can be utilized in various locations, such as geriatric clinics (DeBerry, 1982; Reig-Ferrer et al., 2014). Considering the service network in Brazil, we can infer that this is a treatment that could be applied, without further difficulties, in public service, such as in health centers and family service centers. However, we did not find in this review any study about Relaxation Techniques in elderly people performed in Brazil. 


\section{Final considerations}

This systematic review found evidence of the effectiveness of Relaxation Techniques for the elderly population. The main benefits of relaxation in this population are observed in two great areas: 1. reduction of anxiety symptoms, as well as cognitive difficulties related to it (attention and memory); 2. reduction of physical symptoms, especially tension headache and immunity increase through decline of stress consequences.

Since it is a technique with low cost and easy application, this review suggests the development of future studies with the following subjects: 1. clinical research seeking to isolate relaxation therapeutic elements, comparing them with control groups; 2 . investigation of symptoms related to anxiety, focusing on cognitive difficulties and immunological parameters related to it, as well as peripheral symptoms, such as pain and psychosomatic disorders; 3. realization of studies with elderly people in different cultures, and among them, in Brazil.

We determined that one of the limitations in our research refers to the analysis of studies with different relaxation techniques, by the manner in which the search and selection of the studies was held. We suggest that future systematic reviews could focus on a specific relaxation technique, investigating its effects, benefits and/or harms when comparing the same procedure in different studies. Another limitation perceived was the use of a string with few research terms, even though the same were indicated in databases such as MESh and Thesaurus, the use of a higher number of terms composing the string in future systematic reviews could result in a wider and more complete study.

Lastly, we hope the results of this research can be useful to the increase of relaxation response investigation as a whole, especially related to the use of techniques effective to the increase of well-being and life quality during aging. In addition, we also desire that more studies are able to contribute for the implementation of Relaxation Techniques application in public health systems and that it helps the qualification of professionals, so they can make use of these techniques in the elderly population as an important therapeutic and preventative asset.

\section{References}

Arena, J. G., Hightower, N. E., \& Chong, G. C. (1988). Relaxation therapy for tension headache in the elderly: A prospective study. Psychology and Aging, 3(1), 96-98. doi:10.1037/0882-7974.3.1.96

Argimon, I. I. de L., Stein, L. M., Xavier, F. M. de F., \& Trentini, C. M. (2004). O impacto de atividades de lazer no desenvolvimento cognitivo de idosos. Revista Brasileira de Ciências do Envelhecimento Humano, 1(1), 38-47. doi:10.5335/rbceh.2012.43

Argimon, I. I. de L., Esteves, C. S., \&Wendt, G. W. (Eds.). (2015). Ciclo Vital: perspectivas contemporâneas em avaliação e intervenção. Porto Alegre, RS: Edipucrs.

Azambuja, R. (2000). Dermatologia Integrativa: a pele em novo contexto. An.bras.dermatol.,75(4), 393-420. (DOI INEXISTENTE)

Bandelow, B., \& Michaelis, S. (2015). Epidemiology of anxiety disorders in the 21st century. Dialogues in Clinical Neuroscience, 17(3), 327. (DOI INEXISTENTE)

Bebbington, A. C. (1988). The expectation of life without disability in England and Wales. Social Science \& Medicine, 27(4), 321-326. doi:10.1016/02779536(88)90265-1

Benson, H., \&Stark, M. (1998). Medicina Espiritual (5th ed.). Rio de Janeiro, RS: Campus.

Bhayat, F., Das-Gupta, E., Smith, C., McKeever, T., \& Hubbard, R. (2009). The incidence of and mortality from leukaemias in the UK: a general population-based study. BMC Cancer, 9, 252. doi:10.1186/1471-2407-9-252

Burmeister, S. B., Esteves, C. S., Argimon, I. I. de L., \& Cataldo, A. Neto. (2016). Reflexões sobre qualidade de vida e envelhecimento. In Atualizações em Geriatria e Gerontologia VI Envelhecimento e Saúde Mental (pp. 341-352). Porto Alegre, RS: Edipucrs. (DOI INEXISTENTE)

Camargos, M. C. S., \& Gonzaga, M. R. (2015). Viver mais e melhor? Estimativas de expectativa de vida saudável para a população brasileira. Cadernos de Saúde Publica, 31(7), pp. 1460-1472. doi:10.1590/ 0102-311X00128914

Chang, B.-H., Casey, A., Dusek, J. A., \& Benson, H. (2010). Relaxation response and spirituality: Pathways to improve psychological outcomes in cardiac rehabilitation. Journal of Psychosomatic Research, 69(2), 93-100. doi:10.1016/j.jpsychores.2010.01.007

DeBerry, S. (1982). The effects of meditation-relaxation on anxiety and depression in a geriatric population. Psychotherapy: Theory, Research\&Practice, 19(4), 512-521. doi:10.1037/hoo88465

Epstein, G. (2009). Imagens que Curam: práticas de visualização para a saúde física e mental. São Paulo, SP: Ágora. 
Fox, M., Knapp, L. A., Andrews, P. W., \&Fincher, C. L. (2013). Hygiene and the world distribution of Alzheimer's disease: Epidemiological evidence for a relationship between microbial environment and age-adjusted disease burden. Evolution, Medicine, and Public Health, 2013(1), 173-186. doi: 10.1093/emph/eot015

Friedman, L., Bliwise, D. L., Yesavage, J. A., \& Salom, S. R. (1991). A Preliminary Study Comparing Sleep Restriction and Relaxation Treatments for Insomnia in Older Adults. Journal of Gerontology, 46(1), P1-P8. doi:10.1093/geronj/46.1.P1

Galvin, J. A., Benson, H., Deckro, G. R., Fricchione, G. L., \& Dusek, J. A. (2006). The relaxation response: Reducing stress and improving cognition in healthy aging adults. ComplementaryTherapies in ClinicalPractice, 12(3), 186-191. doi:10.1016/j. ctcp.2006.02.004

Garcia-Garcia, C., Molina, L., Subirana, I., Sala, J., Bruguera, J., Arós, F., ... Elosua, R. (2014). Sex-based Differences in Clinical Features, Management, and 28-day and 7-year Prognosis of First Acute Myocardial Infarction. RESCATE II Study. Revista Española de Cardiología (English Edition), 67(1), 28-35 doi:10.1016/j.rec.2013.06.024

Jacobson, E. (1924). The technic of progressive relaxation. The Journal of Nervous and Mental Disease, 60(6), 568-578. doi:10.1097/00005053-192412000-00002

Jacobson, E. (1925). Progressive Relaxation. The American Journal of Psychology, 36(1), 73-87. doi:10.2307/1413507

Kuller, L. H., \& Lopez, O. L. (2011). Dementia and Alzheimer's disease: A new direction. The 2010 Jay L. Foster Memorial Lecture. Alzheimer's \& Dementia, 7(5), 540-550. doi: 10.1016/j.jalz.2011.05.901

Lichstein, K. L., \& Johnson, R. S. (1993). Relaxation for insomnia and hypnotic medication use in older women. Psychology and Aging, 8(1), 103-111. doi:10.1037/0882-7974.8.1.103

Lichstein, K. L., Riedel, B. W., Wilson, N. M., Lester, K. W., \& Neal, R. (2001). Relaxation and sleep compression for late-life insomnia: A placebo-controlled trial. Journal of Consulting and Clinical Psychology, 69(2), 227-239. doi: 10.1037/0022-006X.69.2.227

Organização Mundial da Saúde. (2005). Envelhecimento ativo: uma politica de saúde. (Suzana Gontijo, Trans.). Brasilia, DF: Organização Pan-Americana de Saúde. Retrieved from http://bvsms.saude.gov.br/ bvs/publicacoes/envelhecimento_ativo.pdf

Petrov, I. C. (2007). The Elderly in a Period of Transition. Annals of the New York Academy of Sciences, 1114(1), 300-309. doi:10.1196/annals.1396.041

Reig-Ferrer, A., Ferrer-Cascales, R., Santos-Ruiz, A., Campos-Ferrer, A., Prieto-Seva, A., Velasco-Ruiz, I., ... Albaladejo-Blazquez, N. (2014). A relaxation technique enhances psychological well-being and immune parameters in elderly people from a nursing home: A randomized controlled study. BMC Complementary and Alternative Medicine, 14, 1-14. doi:10.1186/1472-6882-14-311
Scogin, F., Rickard, H. C., Keith, S., Wilson, J., \&McElreath, L. (1992). Progressive and imaginal relaxation training for elderly persons with subjective anxiety. Psychology and Aging, 7(3), 419-424. doi:10.1037/0882-7974.7.3.419

The WHOQOL Group. (1995). The World Health Organization quality of life assessment (WHOQOL): Position paper from the World Health Organization. Social Science \& Medicine, 41(10), 1403-1409 doi:10.1016/0277-9536(95)00112-K

Thorp, S. R., Ayers, C. R., Nuevo, R., Stoddard, J. A., Sorrell, J. T., \& Wetherell, J. L. (2009). Meta-analysis Comparing Different Behavioral Treatments for Late-Life Anxiety. The American Journal of Geriatric Psychiatry: Official Journal of the American Association for Geriatric Psychiatry, 17(2), 105-115. doi:10.1097/ JGP.ob013e31818b3f7e

Vivan, A. S. \& Bicca, M.G. (2015). Coping e depressão em idosos. In Argimon, I. I. de L., Esteves, C. S. \& Wendt. G. W. (Eds.), Ciclo Vital: perspectivas contemporâneas em avaliação e intervenção (pp. 267-277). Porto Alegre, RS: Edipucrs.

Yesavage, J. A., \& Jacob, R. (1984). Effects of relaxation and mnemonics on memory, attention and anxiety in the elderly. Experimental Aging Research, 10(4), 211-214. doi:10.1080/03610738408258467

Yesavage, J. A., Rose, T. L., \& Spiegel, D. (1982). Relaxation training and memory improvement in elderly normals: Correlation of anxiety ratings and recall improvement. Experimental Aging Research, 8(4), 195-198. doi:10.1080/03610738208260365

Yu, D. S. F., Lee, D. T. F., \& Woo, J. (2007). Effects of relaxation therapy on psychologic distress and symptom status in older Chinese patients with heart failure. Journal of Psychosomatic Research, 62(4), 427-437. doi:10.1080/03610738208260365

\section{Dados das autoras:}

Andréa dos Santos-Silva, Mestranda - Pontifícia Universidade Católica do Rio Grande do Sul.

Milena Nardini Bubols, Doutoranda - Pontifícia Universidade Católica do Rio Grande do Sul.

Irani Iracema de Lima Argimon, Doutora - Pontificia Universidade Católica do Rio Grande do Sul.

Olivia Stagnaro, Mestra i Santa Clara University.

Letícia Oliveira Alminhana, Pós-Doutorado - Pontifícia Universidade Católica do Rio Grande do Sul.

\section{Endereço para correspondência:}

Andréa dos Santos-Silva

Rua Joaquim Nabuco, 20/405, Porto Alegre, RS, CEP: 90050-340

Telefones: (51) 3024-3910/ (51) 98191-2297 